\title{
Study on Stability Control of Retained Gob-Side Entry by Blasting Fracturing Roof Technology in Thick Immediate Roof
}

\author{
Jingang Guo, ${ }^{1,2}$ Yaohui Li, ${ }^{1,2}$ Fulian He ${ }^{D},{ }^{1}$ GuangSheng Fu, ${ }^{3}$ and Sheng Gao ${ }^{4}$ \\ ${ }^{1}$ School of Energy \& Mining Engineering, China University of Mining \& Technology (Beijing), Beijing 10083, China \\ ${ }^{2}$ Datong Coal Mine Group Co., Ltd, Datong 037003, China \\ ${ }^{3}$ Shandong Bureau of China Metallurgical Geology Bureau, Qingdao 26600, China \\ ${ }^{4}$ CCTEG Energy Technology Development Co., Ltd, Beijing 10083, China
}

Correspondence should be addressed to Fulian He; hwfrl323@sohu.com

Received 4 October 2020; Revised 23 October 2020; Accepted 12 April 2021; Published 20 April 2021

Academic Editor: Mickaël Lallart

Copyright (๑) 2021 Jingang Guo et al. This is an open access article distributed under the Creative Commons Attribution License, which permits unrestricted use, distribution, and reproduction in any medium, provided the original work is properly cited.

\begin{abstract}
A retained gob-side entry technique is popular in longwall mining coal mines, because the excavation of an entry is reduced for the next panel. However, it is influenced by multiple excavations and mining, so the stability control of the surrounding rock becomes a problem. In view of the above problems, a typical retained gob-side entry with thick immediate roof was carried out, and a blasting fracturing roof technology was used in it to improve the stress environment, reduce the deformation and damage, and ensure stability and safety. To study the fracturing roof parameters, a global model with thick immediate roof considering strainsoft and double-yield constitution was built. It found that the stress, damage range, and deformation of surrounding rock were closely related to the height and angle of fracturing roof, and an optimal case was given out. The simulation result was applied to the field practice, and a good application effect was achieved. The above technique and research method can be used as a reference for the coal mine with similar conditions.
\end{abstract}

\section{Introduction}

More than $90 \%$ of underground mines use longwall mining methods in China [1]. The longwall working panel is composed of a mining face and two entries for ventilation, transportation, and walking. A coal pillar was usually set between two panels to space the gob (Figure 1(a)), but it causes huge waste of coal resources $[2,3]$. The strike length of large longwall mining panel is usually several kilometers, and the entry excavation needs a lot of manpower, resources, and time, which may lead to the tension between mining and excavation. Meanwhile, the ventilation of this mining scheme is " $U$ " type, which is not conducive to the safe production of high-gas coal mines $[4,5]$. To avoid the above problems, many coal mines use retained gob-side entry with artificial supports (Figure 1(b)) to control the stability of surrounding rocks, reduce coal waste and excavation quantities, and improve the ventilation type [6]. However, this mining scheme could not efficiently improve stress of surrounding rock, and the construction of artificial support is also time-consuming and laborious. In recent years, a blasting fracturing roof technology (BFRT) is widely used in China to retain gob-side entry (Figure 1(c)). This technology can change the stress environment of retained gob-side entry through adjusting roof occurrence state. The stability of gob-side entry could be ensured without coal pillar and artificial support, which greatly reduces the construction cost and time $[7,8]$.

Scholars and engineers had made a lot of researches on BFRT, which focused on the influences of the fracturing methods and parameters and the overburden roof structures before and after BFRT above retained gob-side entry. At present, the main fracturing roof methods are blasting, hydrofracturing, and electric saw. Zhang et al. [9] studied the parameters of blasting fracturing roof through LS-DYNA3D simulation software, the effective stress in the roof during blasting was presented, and spacings of boreholes were optimized and good results had been achieved in the field practice. Huang et al. [10] applied the hydrofracturing method to cut the 


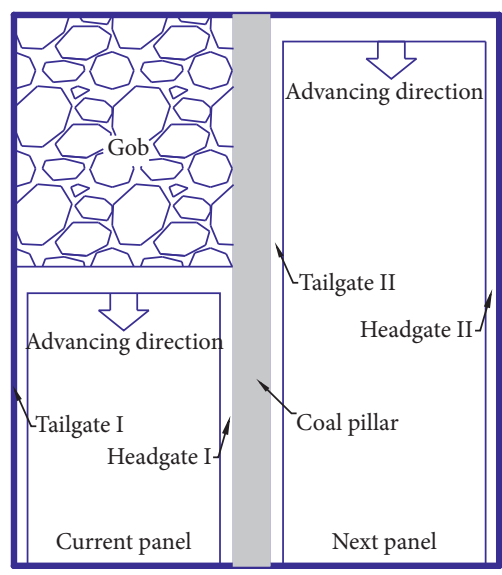

(a)

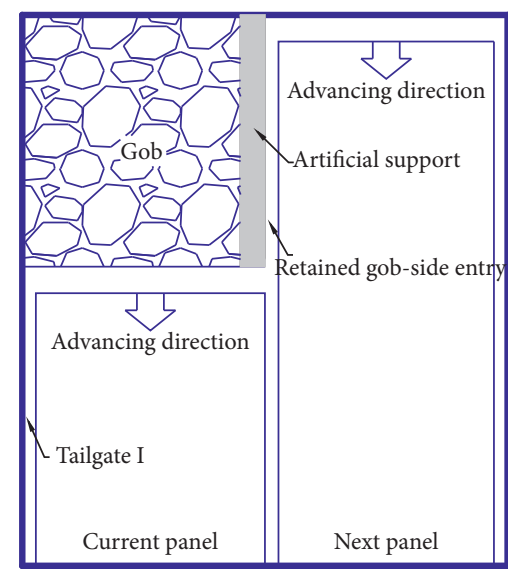

(b)

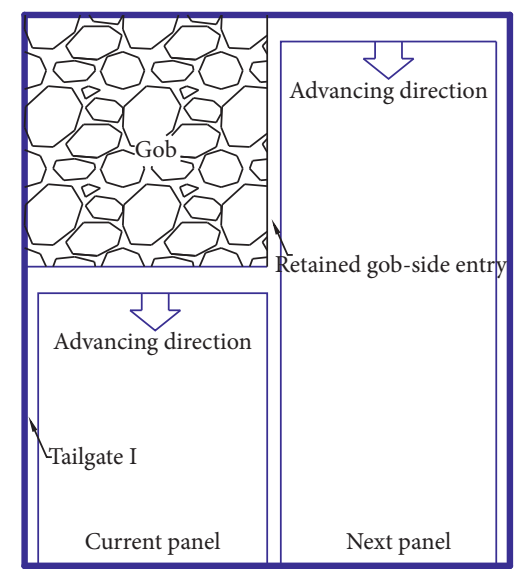

(c)

Figure 1: Typical longwall mining scheme. (a) Coal pillar. (b) Artificial support. (c) Nonpillar.

roof of retained gob-side entry, an analytical model of directional hydraulic for hanging hard roof in gob-side entry was built to obtain the stress distribution with different the breaking location of roof, and then the influence factors of breaking location were explored to calculate the optimal hydrofracturing position and parameters. Tai et al. [11] introduced an innovative BFRT with a chainsaw arm and equipment, the vertical stress around retained gob-side entry was studied by simulation analysis, and they pointed out that the stress decreased by $25 \%$ after using this method.

In BFRT parameter researches, Ma et al. [12] studied the fracturing angle by theoretical analysis and mechanical tests and concluded that the fracturing angle had a great influence on stress around surrounding rocks; and a rational fracturing angle was given out in a certain geology condition. Hou et al. [13] analyzed the fracturing height through discrete element numerical software UDEC in Nanyang coal mine; they presented that BFRT could efficiently eliminate the crushing damage of the roof, and the deformation decreased with the fracturing height increase. Finally, a rational fracturing height of $18 \mathrm{~m}$ was obtained. He et al. [14] presented a directional fracturing roof technique applied in thick coal seams and a constant resistance and large deformation anchor cable support method, and the rational fracturing height and angle were explored by numerical simulation. This technique was applied to retained gob-side entry, and the deformation of the entry satisfied the mining requirements.

The BFRT can improve the stress environment of surrounding rock through changing occurrence state of roof above retained gob-side entry to reduce the entry deformation and damage. About studies of the surrounding rock deformation mechanism affected by roof structures, Bai et al. [15] found that the hard cantilever beam above the gob-side entry greatly compressed the underlying coal seams through field investigation and numerical simulation, which makes surrounding rock unstable, and pointed out that the great horizontal and vertical stress and elastic energy were the main reasons for the damage of the surrounding rocks. About roof structure after BFRT, Wang et al. [16] built a short cantilever beam mechanical model to study the roof deformation principle and the key effect factors and demonstrated that the roof rotation angle after BFRT and entry width had great effect on roof deformation. Yang et al. [17] found that fracturing roof could form a stable structure when the fracturing angle was not zero and the height was higher than mining thick through equivalent material simulation experiment. To control the stability of the gob-side entry, they suggested paying attention to not only the supports of the coal body and roof stable structure but also the damage of them. Yang et al. [18] explored the roof movement characteristics under different roof fracturing position through theoretical and numerical model and presented that the rational fracturing roof location could made the roof breaking body form a stable caved structure. Zhang et al. [19] compared the hard main roof structure using BFRT above retained gob-side entry with that using traditional artificial support in steeply pitch seams and presented that the caved structure after fracturing roof can avoid the gangue influence and form roadside support to reduce the deformation of retained gob-side entry.

Based on the above researches, this study combined the engineering and geological conditions of thick immediate roof in DDG coal mines, and the surrounding rock stabilities principle of retained gob-side entry by BFRT was set out. A BFRT simulation model with thick immediate roof considering strain-softening and double-yield constitution was built to study the plastic ranges, abutment stress, and deformation of surrounding rock. Then, an optimal fracturing roof case was obtained. Finally, a field test was carried out in retained gob-side entry 5201, and a good application effect was obtained through monitoring the deformations of the surrounding rock around the retained gob-side entry.

\section{Engineering and Geological Conditions and Laboratory Mechanical Tests}

2.1. Engineering and Geological Conditions. The coal seam of test site is nearly horizontal, and the average thickness and the buried depth are $3.6 \mathrm{~m}$ and $450 \mathrm{~m}$, respectively. For the retained gob-side entry 5201 located between panel 8206 and panel 8201 
(Figure 2), panel 8201 is mined first, and then panel 8206 is retreated, and the gob-side entry 5201 serves two panels (panel 8206 and panel 8201). The BFRT is applied in retained gob-side entry 5201 to guarantee the stability of surrounding rocks. The panel mines with comprehensive mechanized equipment. The strata above panel are pelitic siltstone $(8 \mathrm{~m})$, fine sandstone $(5 \mathrm{~m})$, and silty mudstone $(6 \mathrm{~m})$, while the rock strata below the coal seam are mudstone $(1 \mathrm{~m})$ and medium fine sandstone $(10 \mathrm{~m})$. Figure 3 shows the generalized stratigraphy column of the test site. The height and the caved angle of caved zone are $13.3 \mathrm{~m}$ and $45^{\circ}$, respectively.

The width and height of the retained gob-side entry 5201 are $5.2 \mathrm{~m}$ and $3.6 \mathrm{~m}$, respectively. The lengths and diameters of the bolts used in roof are $2500 \mathrm{~mm}$ and $22 \mathrm{~mm}$, respectively. They are setting with the spacing of $1000 \times 1100 \mathrm{~mm}$. The lengths and diameters of the anchors in roof are $8300 \mathrm{~mm}$ and $17.8 \mathrm{~mm}$, their spacings are $2000 \times 1300 \mathrm{~mm}$, and they are all connected with "W" steel belts. The support structures of two coal ribs are symmetrical, and the lengths, diameters, and spacings of the bolts in ribs are $2000 \mathrm{~mm}, 22 \mathrm{~mm}$, and $1000 \times 1000 \mathrm{~mm}$. Metal meshes are laid on the roof and two ribs. After panel 8201 retreats, an anchor and a hydraulic prop are added in every row to support the roof, and two gangue baffles are applied to blocking gangues in each row, the height and thickness of the gangue baffle are $124 \mathrm{~mm}$ and $16 \mathrm{~mm}$, respectively, and two gangue baffles are arranged for each row. The length and diameter of the anchor added in the edge of the roof are $10300 \mathrm{~mm}$ and $17.8 \mathrm{~mm}$, respectively, and the load of hydraulic props is $100 \mathrm{kN}$. The specific support parameters are shown in Table 1 and Figure 4.

2.2. Laboratory Mechanical Tests. The rock and coal samples were drilled from panel 8201 and made in the laboratory, and they are shown in Figure 5. The mechanical tests were manipulated on a triaxial testing machine (TAW-1000 kN). The elastic modulus $E$, the uniaxial compression strength $\sigma_{c}$, the uniaxial tensile strength $\sigma_{t}$, Poisson's ratio $v$, the cohesion $c$, and the friction angle $\Phi$ are tested. The mechanical parameters of coal and rock are listed in Table 2.

\section{Surrounding Rock Control Mechanism Using BFRT}

After the panel retreats, the caved zone and fracture zone are formed above gob during overlying strata breaking and caving, and there will be a cantilever beam above the retained gob-side entry (Figure 6(a)). Because there is no support below the cantilever beam, the own weight and overburden loads of overhang zone make it bend, and the loads transform to the gob gangue and virgin coal rib. Due to the weak bearing capacity of the gob gangue, the virgin coal rib will bear most of the loads. Meanwhile, the own weight and overburden loading can form a great bending movement forcing, which compress the surrounding rock around retained gob-side entry. Therefore, the existence of overhang zone makes it difficult to maintain the stability of the surrounding rock, which has a huge impact on safety and production.

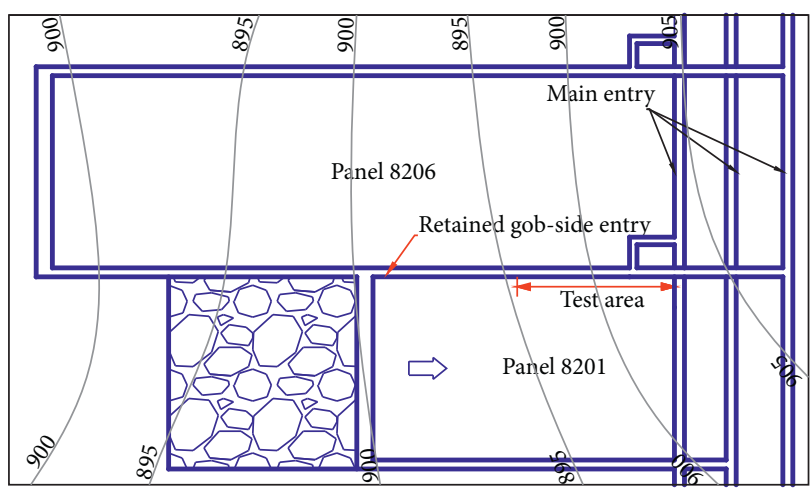

FIGURE 2: Location of 5201 retained gob-side entry.

\begin{tabular}{|c|c|c|}
\hline Thickness (m) & Figure & Lithology \\
\hline 430 & & Overlying strata \\
\hline 6 & & Silty mudstone \\
\hline 5 & & Fine sandstone \\
\hline 8 & & Pelitic siltstone \\
\hline 1 & & Coal \\
\hline 10 & & \begin{tabular}{c} 
Mudstone \\
\hline
\end{tabular} \\
\hline
\end{tabular}

Figure 3: Generalized stratigraphy column of the test site.

TABLe 1: Mechanical parameters of supports.

\begin{tabular}{lcccc}
\hline Type & $L(\mathrm{~mm})$ & $L_{r}(\mathrm{~mm})$ & $D(\mathrm{~mm})$ & $F_{t}(\mathrm{~mm})$ \\
\hline Bolts in roof & 2500 & 1200 & 22 & $2 \mathrm{e} 5$ \\
Bolts in rib & 2000 & 1200 & 22 & $2 \mathrm{e} 5$ \\
Anchor cable & 8300 & 2400 & 17.8 & $2.5 \mathrm{e} 5$ \\
\hline
\end{tabular}

$L$ is the length of the bolt or anchor; $L_{\mathrm{r}}$ is the grout length; $D$ represents the diameters; $F_{\mathrm{t}}$ is tensile strength.

The BFRT forms a fracturing line above the retained gobside entry through deep hole blasting in this study (Figure 6(b)), and then the cantilever beam weight and overburden loading make it breaking along the fracturing line to reduce the overhang length, which can decrease the influence of own weight and overburden loads on the surrounding rocks, improve the stress environment, and guarantee the stability of the retained gob-side entry.

\section{Numerical Simulation Study of BFRT}

\subsection{Study Model and Scheme}

4.1.1. Global Model. According to surrounding rock control mechanism using BFRT, the fracturing height and angle are key parameters in BFRT. A numerical simulation was built to obtain the rational fracturing height and angle (Figure 7), and 


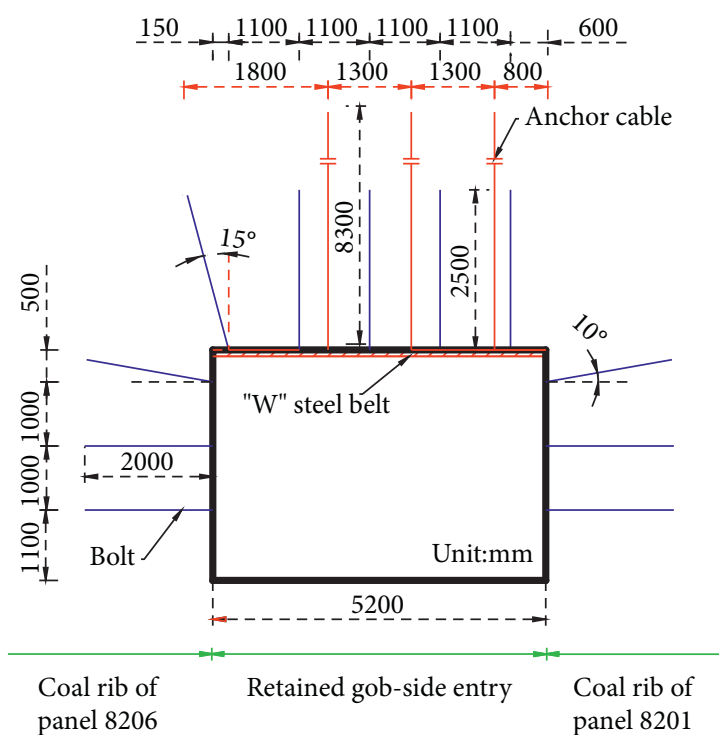

(a)

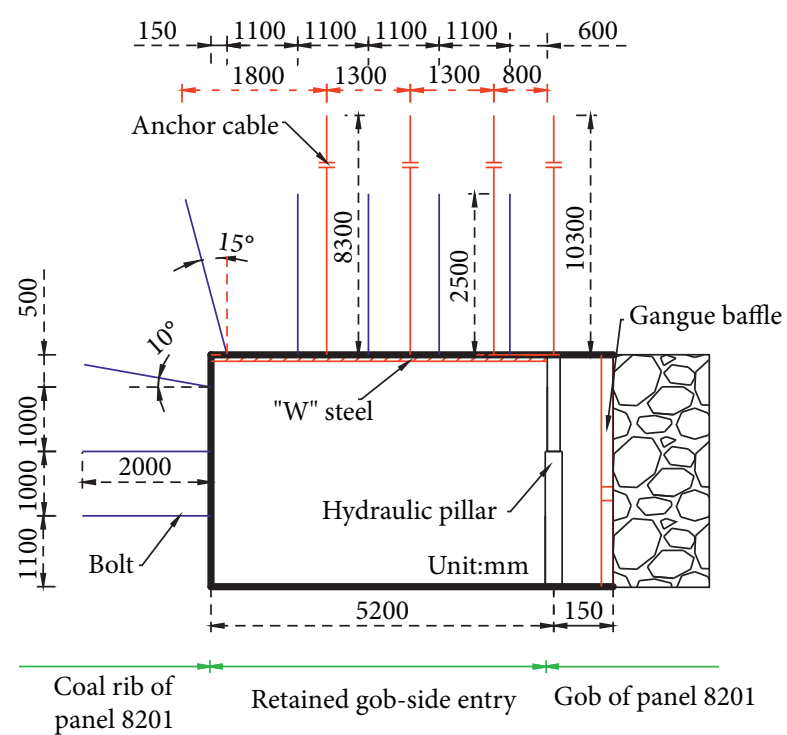

(b)

Figure 4: Supports of gob-side entry 5201. (a) Before panel 8201 retreats. (b) After panel 8201 retreats.

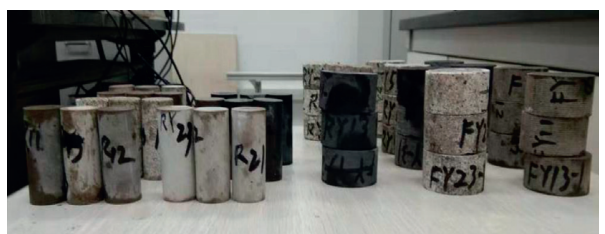

FIGURE 5: Rock and coal samples.

TABLE 2: Mechanical parameters of coal and rock.

\begin{tabular}{lcccccc}
\hline Lithology & $E(\mathrm{GPa})$ & $\sigma_{c}(\mathrm{MPa})$ & $\sigma_{t}(\mathrm{MPa})$ & $v$ & $c(\mathrm{MPa})$ & $\Phi(\mathrm{deg})$. \\
\hline Silty mudstone & 11.3 & 29 & 1.8 & 0.29 & 6.8 & 35 \\
Fine sandstone & 50.9 & 86.7 & 2.8 & 0.24 & 13.2 & 11.1 \\
Pelitic siltstone & 30.4 & 50.4 & 2.2 & 0.28 & 3.3 \\
Coal & 5.8 & 9.1 & 1.4 & 0.32 & 0.3 & 5.3 \\
Mudstone & 9.7 & 21.1 & 1.59 & 2.7 & 0.26 & 11.7 \\
Medium fine sandstone & 46.4 & 39.5 & & &
\end{tabular}

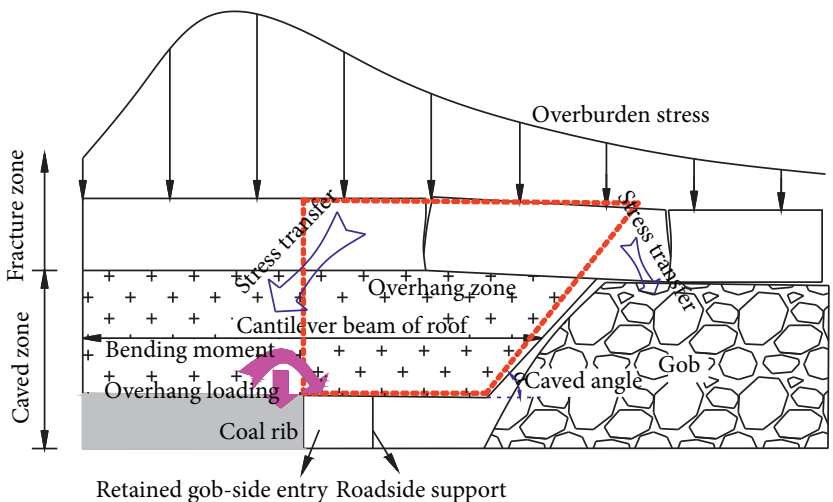

(a)

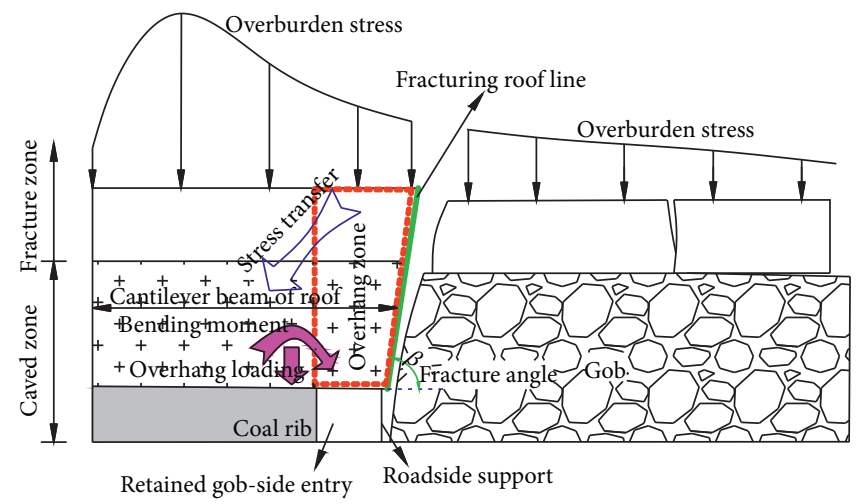

(b)

FIGURE 6: Surrounding rock control mechanism using BFRT. (a) Before BFRT. (b) After BFRT. 
its size is $380 \mathrm{~m} \times 53 \mathrm{~m} \times 10 \mathrm{~m}$. The vertical stress of $10.2 \mathrm{MPa}$ was applied to the top of the model to simulate the overburden stratum loads and the gravity is considered. The horizontal stresses of 1.2 times the vertical stress were applied to the model in the horizontal direction. The bottom and four sides were constrained. The soft-strain and double-yield constitutions are applied to coal seam and gob, respectively. The other strata used Mohr-Coulomb constitution.

4.1.2. Study Cases. Numerical simulation sets up seven groups of cases. The BFRT is not applied in Case 7, the roof above the retained gob-side entry is naturally caving, and the caved height $H$ and angle $\alpha$ of the caved zone are presented in Section 2.1. The fracturing heights of cases 1, 2, and 3 are $13 \mathrm{~m}$, the fracturing roofs are immediate and main roofs, and the fracturing angles $\beta$ of these cases are $60^{\circ}, 75^{\circ}$, and $90^{\circ}$ (Figure $8(\mathrm{a})$ ). The fracturing height of cases 4,5 , and 6 is $8 \mathrm{~m}$ (Figure $8(\mathrm{~b})$ ), the fracturing roof is immediate roof, and the fracturing angles $\beta$ of these cases are $60^{\circ}, 75^{\circ}$, and $90^{\circ}$. The parameters of cases are listed in Table 3 .

4.2. Simulation Parameters Determination. Rock mechanical parameters play an important role for numerical simulation results. The mechanical properties of rock and coal samples obtained in laboratory do not consider fractures and joints in the rock and coal masses, which could not truly reflect the mechanical properties of rock and coal masses. The mechanical properties of coal and rock masses can be achieved by revising strength of intact rocks. Therefore, the mechanical parameters of rock and coal samples are revised to apply to numerical simulation through RocLab software, and they are shown in Table 4.

$$
\sigma_{1}=\sigma_{3}+\sigma_{c i}\left(m_{b} \frac{\sigma_{3}}{\sigma_{c i}}+s\right)^{a},
$$

where $\sigma_{c i}$ is the uniaxial compressive strength and $\sigma_{1}$ and $\sigma_{3}$ are the maximum and minimum principle stresses, respectively. $m_{\mathrm{b}}, s$, and $a$ are the constants, and they can be obtained from the following equations:

$$
\begin{aligned}
m_{b} & =m_{c i} \exp \left(\frac{\mathrm{GSI}-100}{28-14 \mathrm{D}}\right), \\
s & =\exp \left(\frac{\mathrm{GSI}-100}{9-3 \mathrm{D}}\right), \\
a & =0.5+\frac{1}{6}\left(e^{-(\mathrm{GSI} / 15)}-e^{-(20 / 3)}\right),
\end{aligned}
$$

where $m_{c i}$ is a constant of the intact rock, $D$ is the disturbance coefficient, and GSI represents the evaluation parameters of the fracture rock.

The failure process of coal includes elastic stage, plastic stage, and residual stage. Zhang et al. [20] presented that a strain-soft constitution can more truly simulate the above stages. Therefore, the strain-soft constitution is applied to the coal seams in this study, and the mechanical properties of coal after failure are achieved by changing cohesion and friction; they are obtained by laboratory tests, as shown in Table 5.

\subsection{Application of the Double-Yield Constitution in Gob}

4.3.1. The Parameter Determination of Gangue in Gob. The properties of caved gangue in the gob are crucial for the accuracy of the simulation by Jiang et al. [21]. The doubleyield constitution can achieve the stress changes with the material deformation, which could truly simulate the caved gangue mechanical properties. Therefore, the double-yield constitution is applied in the gangue of gob. The cap pressure is one of the important parameters in the double-yield model. According to studies of Salamon [22], Yavuz [23], and Jiang et al. [24], the cap pressure can be given out by the equations:

$$
\begin{aligned}
& \sigma=\frac{\left(10.39 \sigma_{c}^{1.042} / b^{7.7}\right) \varepsilon}{1-(\varepsilon b /(b-1))}=\frac{10.39 \varepsilon \sigma_{c}^{1.042}}{b^{7.7}(1-(\varepsilon b /(b-1)))}, \\
& b=\frac{h_{c}+h_{c r}}{h_{c r}}
\end{aligned}
$$

where $\sigma_{c}$ is the uniaxial compressive strength of gangue, $\square$ is the strain of gangue, $b$ is the bulk factor, and $h_{c r}$ is the height of the caved zone. The mining height of panel 8201 is $3 \mathrm{~m}$, and caved height is $13.3 \mathrm{~m}$, which is presented in Section 2.1.

The other parameters of gob gangue can be determined by back analysis method. The specific method is to build a cube, apply a fixed velocity on the top of the model, and fix other boundaries. Then the parameters are adjusted to be close to the Salamon analytical results. In this study, the properties of gob gangue are in good agreement with those calculated by Salamon through back analysis method (Figure 9), and the gob gangue properties are listed in Table 6.

4.3.2. Verification of Gob Simulation. To verify the reliability and accuracy of the double-yield model and the parameter choices, the vertical stress in the gob is studied. Figures 10(a) and 1010(b) show vertical stress nephogram and curve, respectively. It can be seen from Figure 10 that the vertical stress gradually increases from $2 \mathrm{MPa}$ to $10.9 \mathrm{MPa}$ from the edge of gob to $60 \mathrm{~m}$ from the edge of gob, and the vertical stress in the middle of the gob $(10.9 \mathrm{MPa})$ is $96.8 \%$ of the original stress (11.25 MPa). Smart and Haley [25] pointed out that the distance from zero to original vertical stress is about 0.12 times of the overburden thickness. In this study, the distance recovered to the original stress is $0.13 \mathrm{~m}$ times the thickness of the overburden $(60 \mathrm{~m} / 450 \mathrm{~m})$. The above data illustrate that the double-yield model and parameters used in the gob are accurate.

\subsection{Simulation Results}

4.4.1. Plastic Zone Distribution. The plastic zone distributions of surrounding rocks under different BFRT are shown in Figure 11. The plastic zone depths of coal rib in cases 1-7 are 


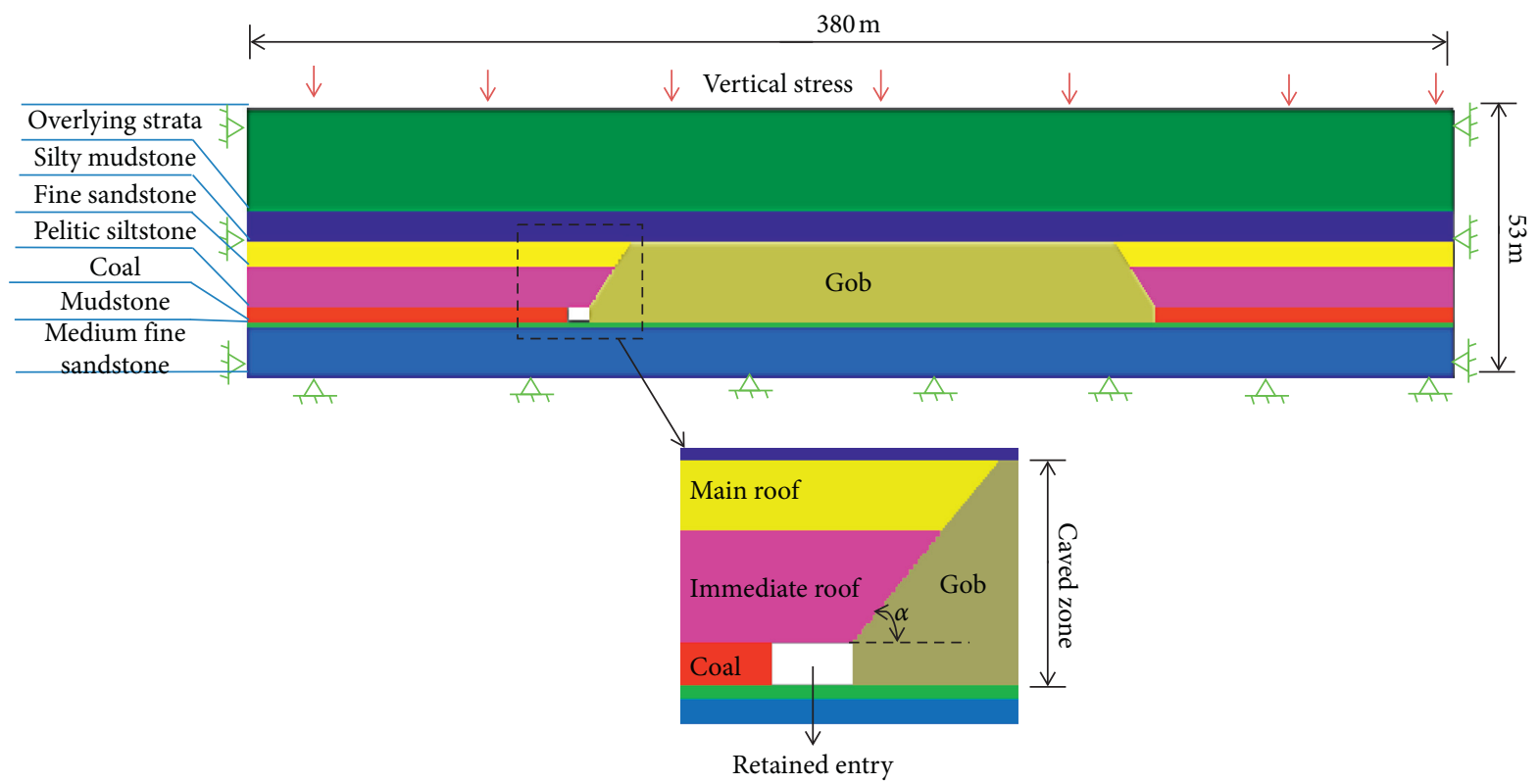

Figure 7: Simulation model.

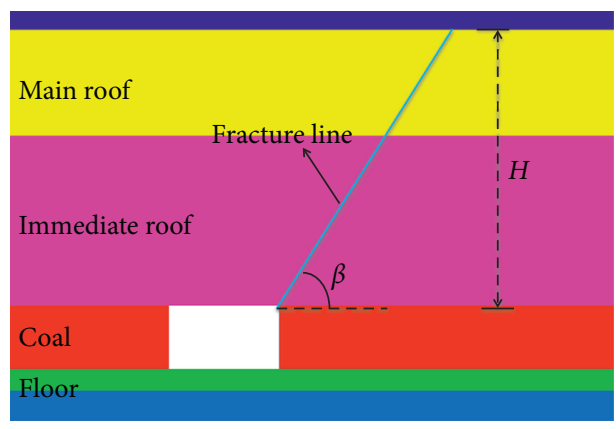

(a)

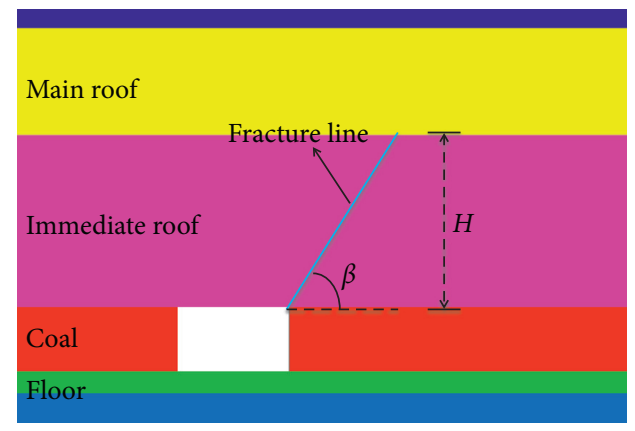

(b)

Figure 8: Simulation schemes. (a) Fracturing immediate and main roof. (b) Fracturing immediate roof.

TABLE 3: Simulation schemes parameters.

\begin{tabular}{lccccccc}
\hline Simulation schemes & Case 1 & Case 2 & Case 3 & Case 4 & Case 5 & Case 6 & Case 7 (nonfracturing) \\
\hline Angle of fracture line (deg.) & 60 & 75 & 90 & 60 & 75 & 90 & $45^{\circ}$ (caved angle) \\
Height of fracturing $H(\mathrm{~m})$ & 13 & 13 & 13 & 8 & 8 & 8 & 13 (caved height) \\
\hline
\end{tabular}

TABLE 4: Rock mass mechanical properties used in numerical simulation.

\begin{tabular}{lccccccccc}
\hline Lithology & GSI & $m$ & $D$ & $E(\mathrm{GPa})$ & $K(\mathrm{GPa})$ & $G(\mathrm{GPa})$ & $\Phi(\mathrm{deg})$. & $C(\mathrm{MPa})$ & $v$ \\
\hline Silty mudstone & 60 & 15 & 0.7 & 6.22 & 4.94 & 2.41 & 34 & 1.1 & 0.29 \\
Fine sandstone & 70 & 17 & 0.7 & 19.1 & 12.2 & 7.70 & 47 & 2.4 & 0.24 \\
Pelitic siltstone & 60 & 10 & 0.7 & 8.21 & 6.22 & 3.21 & 35 & 1.23 \\
Coal & 40 & 8 & 0.7 & 1.1 & 1.02 & 0.42 & 0.28 \\
Mudstone & 45 & 10 & 0.7 & 2.24 & 1.87 & 0.86 & 22.1 & 0.33 & 0.32 \\
Medium fine sandstone & 56 & 15 & 0.7 & 5.77 & 4.01 & 2.29 & 34.6 & 0.3 \\
\hline
\end{tabular}

TABLE 5: Strain-softening parameters of coal.

\begin{tabular}{lcccc}
\hline Strain & 0 & $1 \mathrm{e}-4$ & $5 \mathrm{e}-3$ & \\
\hline Cohesion $(\mathrm{MPa})$ & $2 \mathrm{e} 6$ & 2 & 1.6 & $2 \mathrm{e}-3$ \\
Friction angle $\left({ }^{\circ}\right)$ & 26 & 24 & 23 & 1 \\
\hline
\end{tabular}




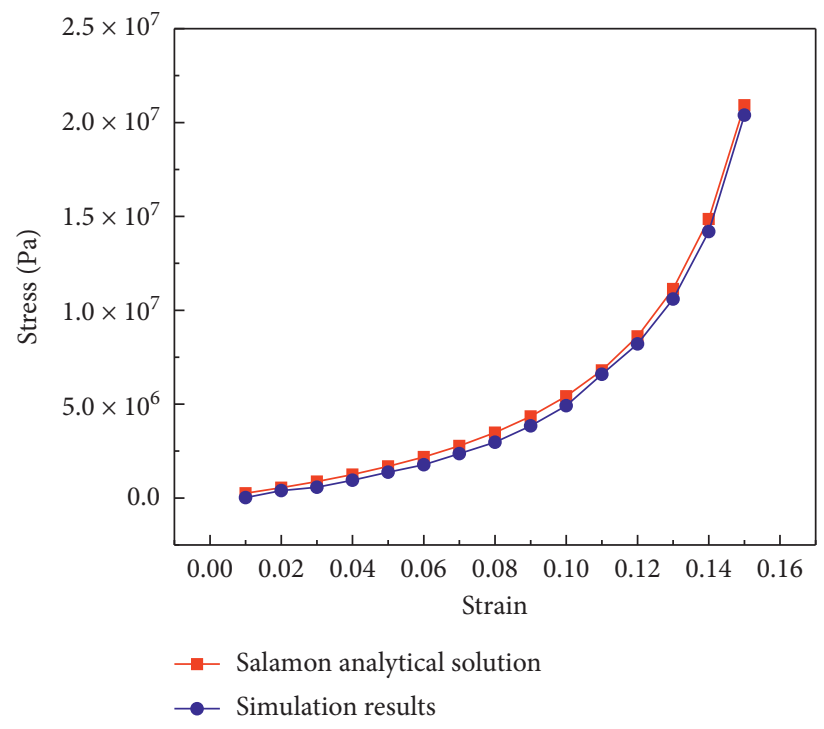

FIGURE 9: Comparison of simulation and analytical results.

TABLE 6: Material parameters of gangue in gob.

\begin{tabular}{lcccccc}
\hline Parameters & Density $\left(\mathrm{kg} / \mathrm{m}^{3}\right)$ & Bulk modulus $(\mathrm{GPa})$ & Shear modulus $(\mathrm{GPa})$ & Friction $\left(^{\circ}\right)$ & Dilation $\left(^{\circ}\right)$ & Tensile $(\mathrm{GPa})$ \\
\hline Value & 1000 & 8.1 & 5.97 & 20 & 6 & 0 \\
\hline
\end{tabular}

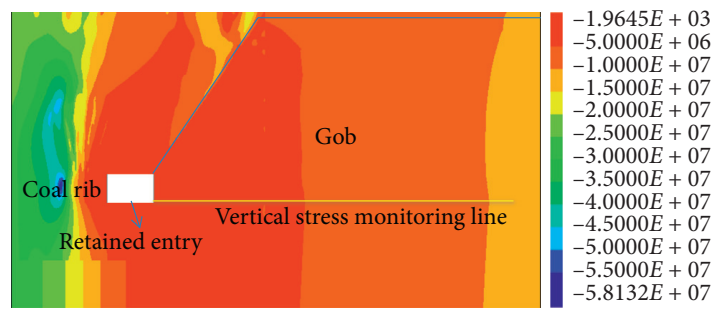

(a)

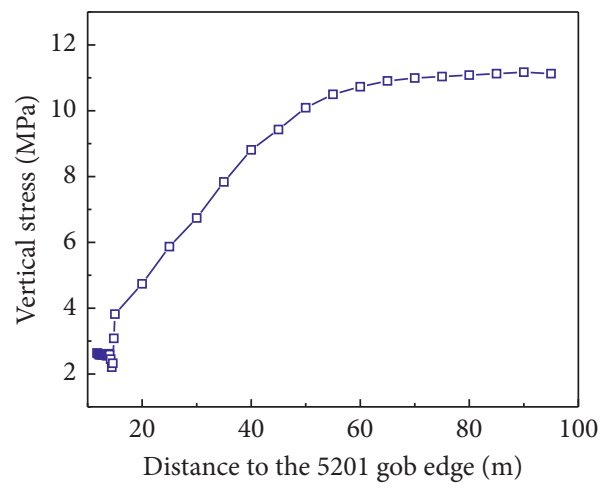

(b)

Figure 10: Vertical stress distribution of gob. (a) Vertical stress nephogram of gob. (b) Vertical stress curve.

$6.6 \mathrm{~m}, 6.4 \mathrm{~m}, 5.2 \mathrm{~m}, 7.0 \mathrm{~m}, 6.8 \mathrm{~m}, 6.8 \mathrm{~m}$, and $7.2 \mathrm{~m}$, while these in floors are $2.4 \mathrm{~m}$. The above data show that the plastic zone depth of coal rib is the greatest when the BFRT is not applied (case 7); it is greatly reduced when the main and immediate roof are fractured (case 1, case 2 , and case 3 ), and the maximum reduction of plastic depth is about $2 \mathrm{~m}$ compared with that without BFRT (case 7). However, the maximum reduction of plastic depth is only $0.4 \mathrm{~m}$ when immediate roof is fractured (case 4, case 5, and case 6) compared with that without BFRT (case 7). Besides, when the fracturing angles are the same, the plastic zone depths of the coal rib under the fracturing main and immediate roof are smaller than those under the fracturing immediate roof; when the fracturing heights are the same, the plastic zone depths decrease with the fracturing angle increasing under fracturing immediate and main roof, while these do not change significantly with the fracturing angle under fracturing main roof.

Meanwhile, the elastic zone location in the roof above retained gob-side entry changes under different cases (Figures 11 and 12). The elastic undamaged zone gradually moves to the top of the retained gob-side entry with fracturing angle decrease. When the fracturing angles are the same, the elastic zone area of fracturing immediate roof is larger than that of fracturing main roof. The elastic zone area is maximum $\left(13.64 \mathrm{~m}^{2}\right)$ under the fracturing immediate and main roof with $90^{\circ}$ (case 3 ), while that is minimum $\left(9.76 \mathrm{~m}^{2}\right)$ under the nonfracturing roof (case 7). The area of elastic zone presents the undamaged area of surrounding rock, and 

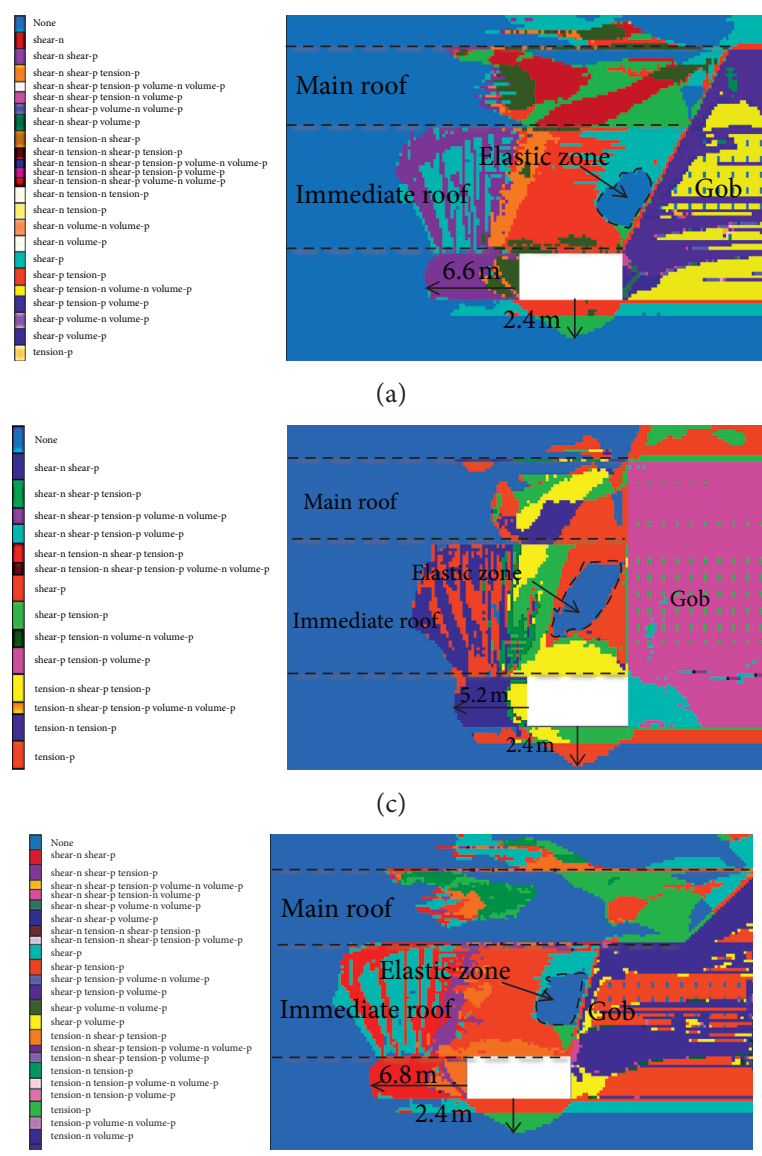

(e)

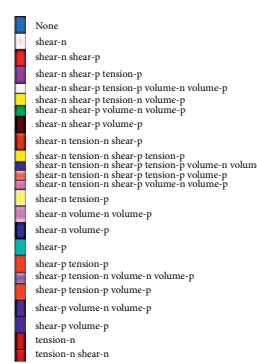

(a)

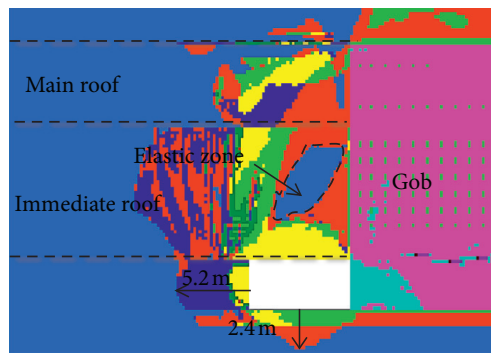

(c)
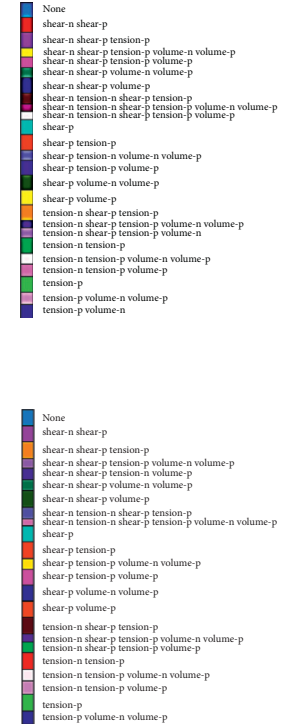

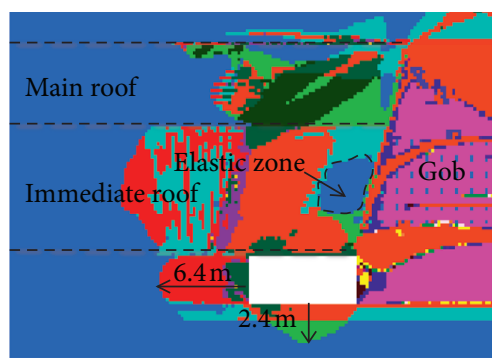

(b)

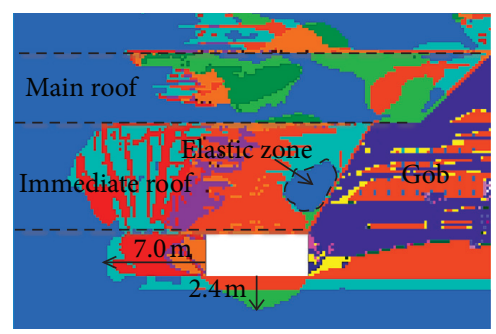

(d)

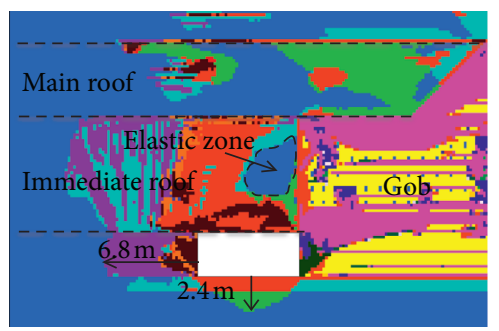

(f)
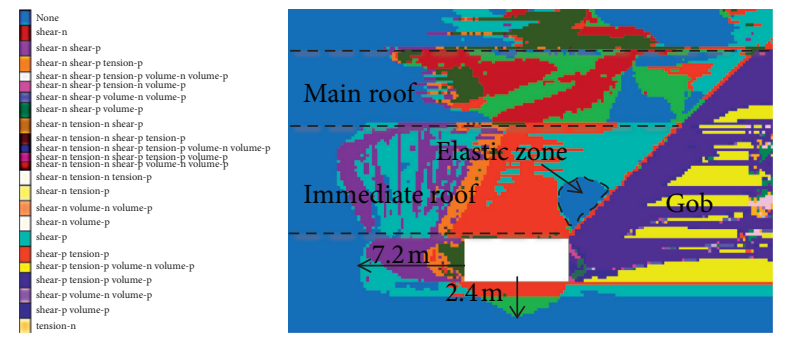

(g)

Figure 11: The plastic zone distribution under different fracturing heights and angles. (a) Case 1 (fracturing main roof with $60^{\circ}$ ). (b) Case 2 (fracturing main roof with $75^{\circ}$ ). (c) Case 3 (fracturing main roof with $90^{\circ}$ ). (d) Case 4 (fracturing immediate roof with $90^{\circ}$ ). (e) Case 5 (fracturing immediate roof with $75^{\circ}$ ). (f) Case 6 (fracturing immediate roof with $90^{\circ}$ ). (g) Case 7 (nonfracturing roof).

the larger the elastic area is, the smaller the damage of surrounding rock is and the better the stability of surrounding rock is. According to the above analysis, fracturing the immediate and main roof and increasing the fracturing are beneficial to reduce the plastic zone depth in coal rib, increase the elastic zone area, and let it locate on the top of the gob-side entry, which can greatly improve the stability of the surrounding rocks.

4.4.2. Abutment Stress Study. The vertical stress distribution in the coal ribs of retained gob-side entry is shown in Figure 13, and the peak values of seven cases are $41.9 \mathrm{MPa}$, 44.9 MPa, 39.8 MPa, 49.2 MPa, 46.5 MPa, 45.0 MPa, and
51.3 MPa, respectively. Based on the distribution principle of the vertical stress of seven cases, it can be obtained that the peak value is minimum $(39.8 \mathrm{MPa})$ and its location is closest to the coal rib $(5.3 \mathrm{~m})$ under the fracturing immediate and main roof with $90^{\circ}$, and the influence range of the abutment stress is smallest. The peak value is maximum $(51.3 \mathrm{MPa})$ and its location is farthest from the coal rib $(7.3 \mathrm{~m})$ under the nonfracturing roof, and the influence range of the abutment stress is largest. When the fracturing heights are the same, the peak value decreases with the fracturing angle increasing; when the fracturing angles are the same, the peak values of the fracturing immediate and main roof decrease compared with the fracturing immediate roof: 


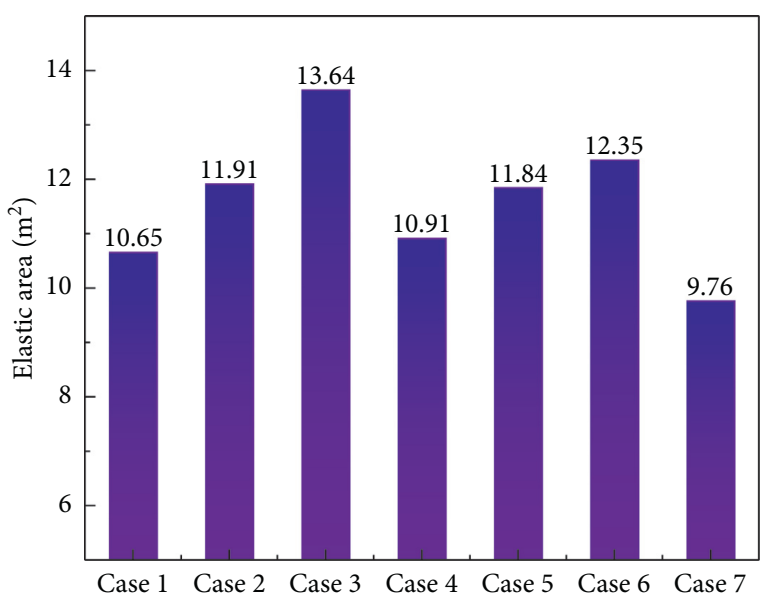

FIGURE 12: Elastic zone area in the roof.

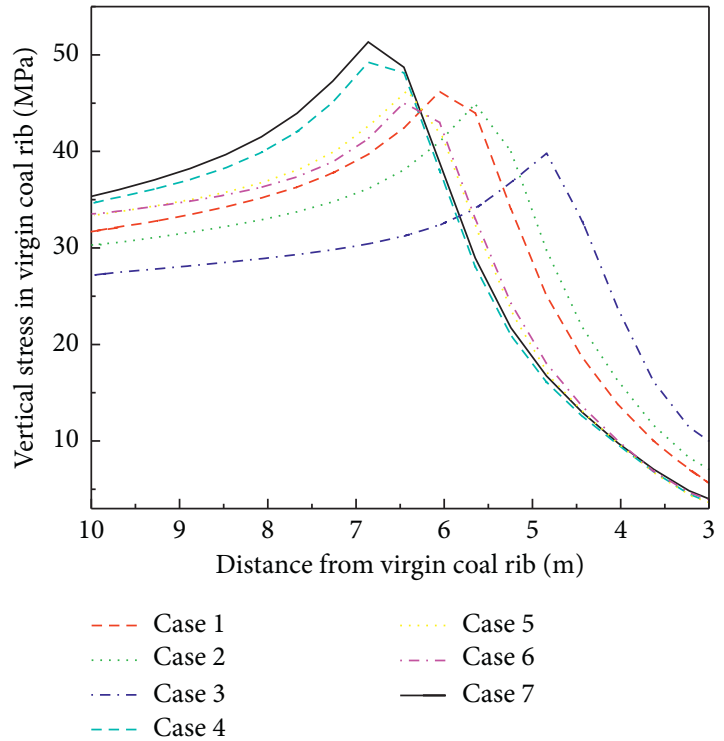

(a)

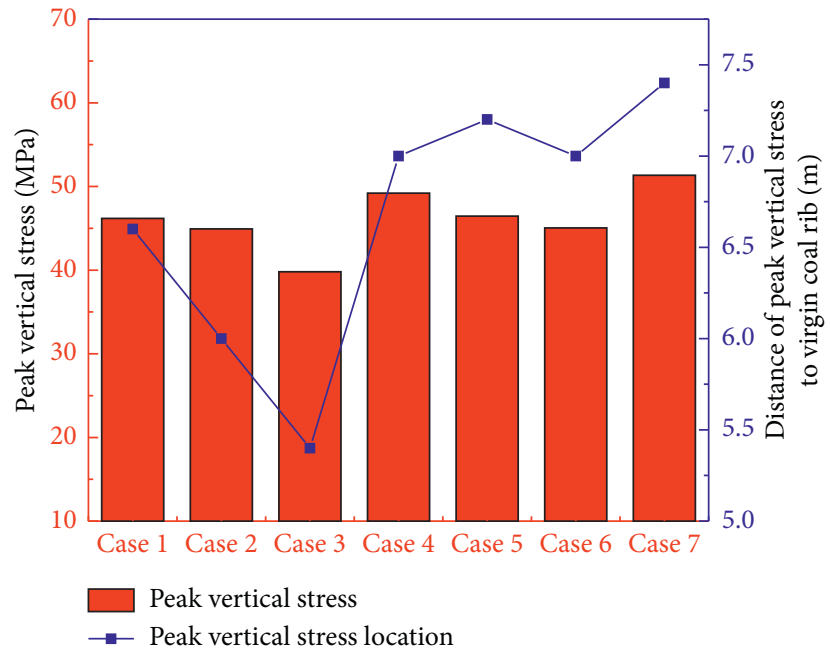

(b)

Figure 13: Vertical stress distribution in the coal ribs of retained gob-side entry. (a) Vertical stress in coal ribs under different fracturing heights and angles. (b) The peak values and locations of the vertical stress in coal rib.

(i) Vertical stress in coal ribs under different fracturing heights and angles

(ii) The peak values and locations of the vertical stress in coal rib

4.4.3. Deformation of the Surrounding Rock. As shown in Figure 14, the deformations of the roof and the coal rib have great differences under seven cases, while there is a little difference between the floors. The deformations of the roof and the coal rib under the cases of the fracturing immediate roof and main roof are significantly less than that under the case of the fracturing main roof. When the fracturing heights are the same, the larger the fracturing angle is, the smaller the deformations of the roof and the coal rib are. The deformations of the roof $(27.8 \mathrm{~mm})$ and the coal rib $(35.4 \mathrm{~mm})$ are minimum under the cases of fracturing immediate and main roof with $90^{\circ}$. According to the roof deformation shown in Figure 14(a), the maximum roof deformations in case 5 and case 6 are $40.5 \mathrm{~mm}$ and $43.7 \mathrm{~mm}$, respectively, which are both greater than that in case $7(40 \mathrm{~mm})$. The reason for the above phenomenon is that the main roof still overhangs after only the immediate roof is fractured and it loses the support of the overhang immediate roof, which makes the own weight of the main roof and the overburden loading transfer to the surrounding rocks around the retained gob-side entry, so the great pressure and bending movement act on the roof. This is why the roof deformation after fracturing immediate roof is greater than that without fracturing roof.

Based on the above analysis, comparing the seven cases, it is found that case 3 (fracturing immediate and main roof 

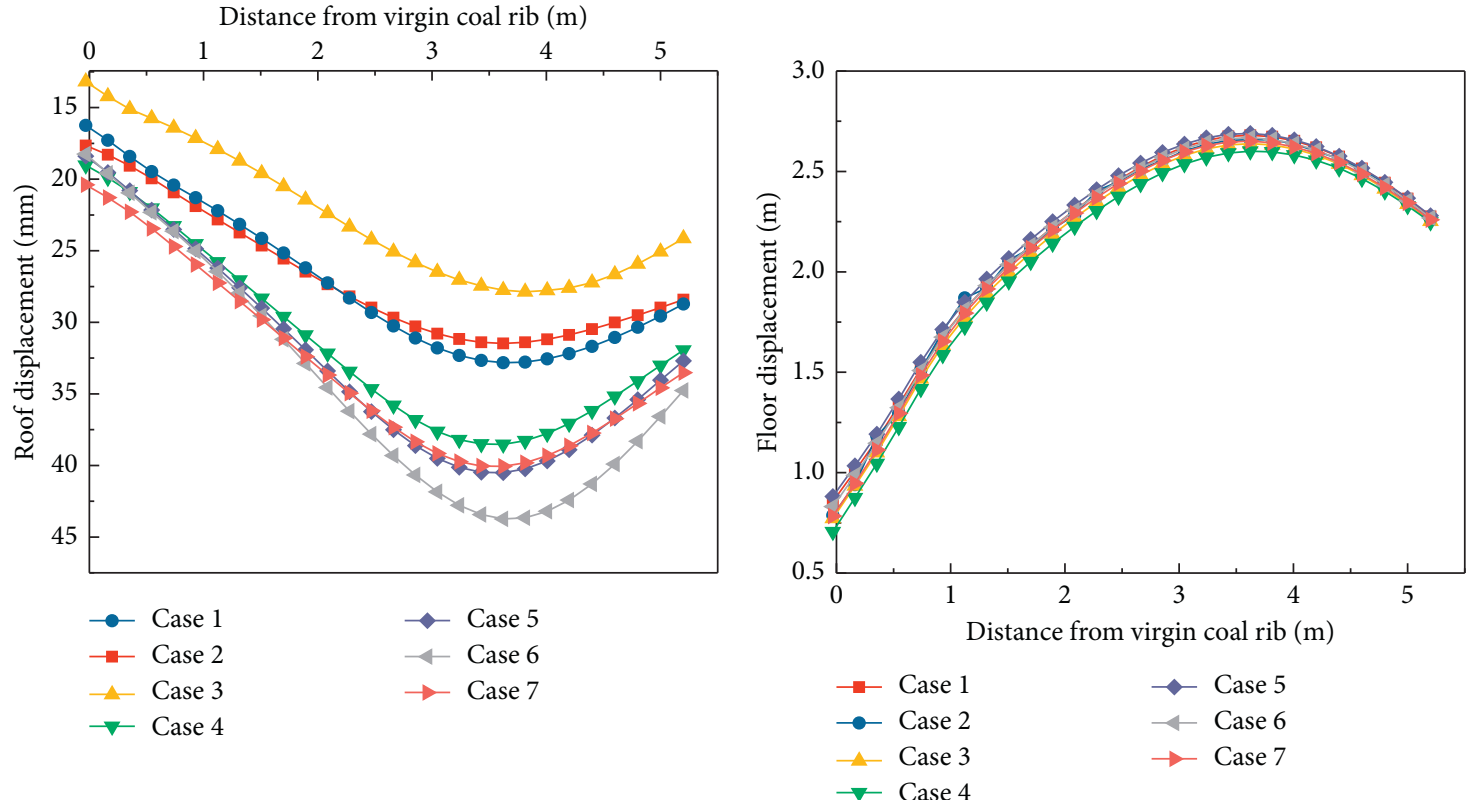

(a)

(b)

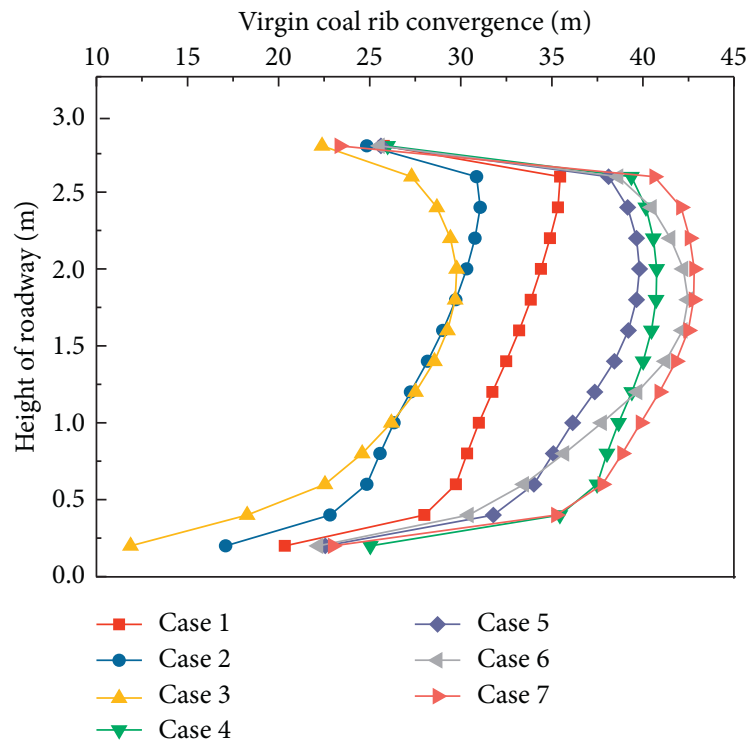

(c)

FIGURE 14: The deformation of the surrounding rocks under different fracturing cases. (a) Roof displacement. (b) Floor displacement. (c) Virgin coal rib convergence.

with $90^{\circ}$ ) is optimal to control the stability of retained gobside entry, which can improve the stress environment and decrease the ranges of plastic zone and deformations of the surrounding rock.

\section{Field Tests}

The BFRT is applied to the retained gob-side entry 5201 with thick immediate roof to study the application effect. Based on the simulation results and construction site technical problems, the diameter and the length of the blasting borehole applied in field tests are $48 \mathrm{~mm}$ and $12500 \mathrm{~mm}$, respectively, the main and immediate roof are fractured, and the fracturing angle is set as $85^{\circ}$. The arrangement and detection pictures after blasting of the borehole are shown in Figure 15.

The surrounding rock deformations of retained gob-side entry are monitored, and the results are in Figure 16. The change of surrounding rock in the $0-50 \mathrm{~m}$ section of lagging work face is small, while that is great in the $50 \mathrm{~m}-140 \mathrm{~m}$ section. In the $140 \mathrm{~m}-200 \mathrm{~m}$ section, the change of surrounding rock deformation is smooth. It can be seen from 


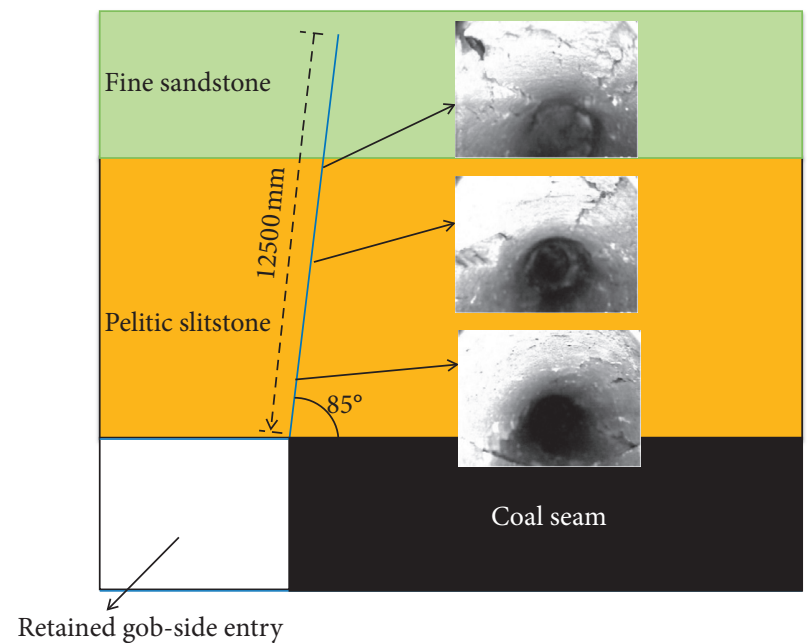

Figure 15: The arrangement and detection pictures of the borehole.

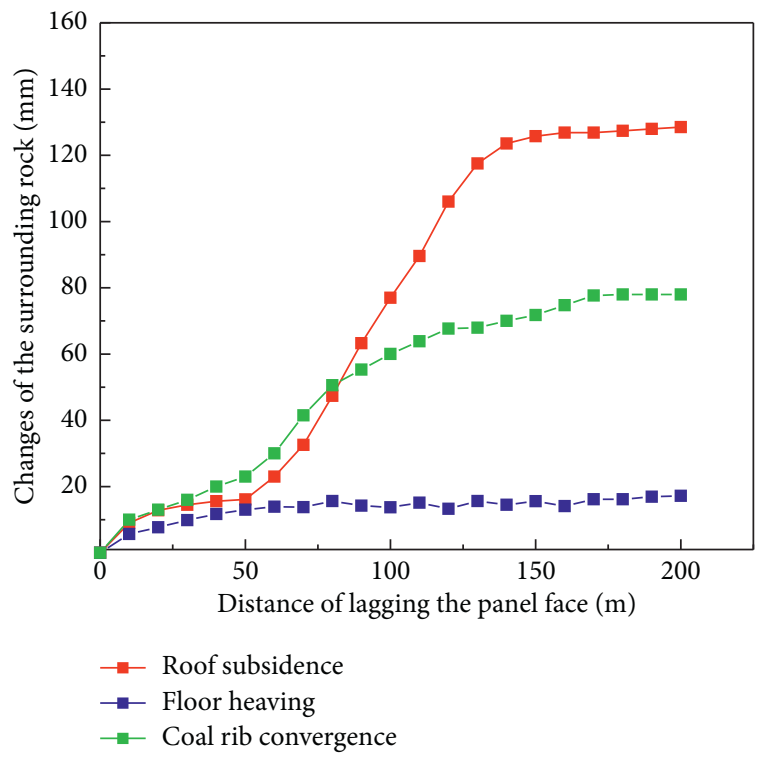

(a)

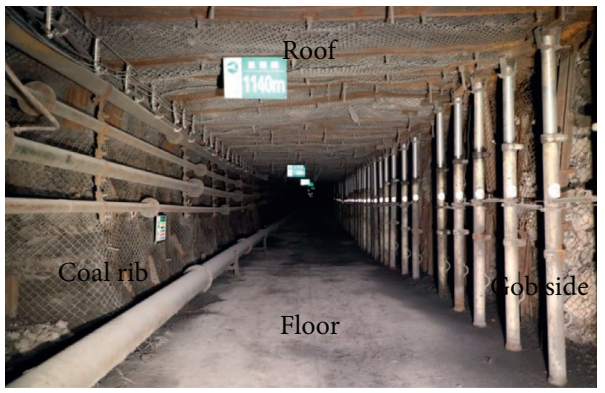

(b)

FIGURE 16: Surrounding rock control effect. (a) Changes of the surrounding rock. (b) Photo of retained gob-side entry.

Figure 16(a) that the maximum deformation changes of the roof, the coal rib, and floor are $128 \mathrm{~mm}, 78 \mathrm{~mm}$, and $17 \mathrm{~mm}$, respectively. The above-mentioned data show that the stability of the surrounding rock around retained gob-side entry is well controlled by BFRT, and the field support effect is shown in Figure 16(b).

\section{Conclusions}

According to the geological condition of thick immediate roof above retained gob-side entry, the numerical simulations considering strain-softening and double-yield constitution are built. Seven cases are studied and compared, and an optimal
BFRT case (fracturing immediate and main roof with $90^{\circ}$ ) is obtained, which can well control the stability of the retained gob-side entry.

Based on numerical simulation, it is known that the BFRT can efficiently improve the stress environment and reduce the plastic zone ranges and deformation of the surrounding rock. When the fracturing angles are the same, the control effects of surrounding rock by fracturing immediate and main roof are better than that by fracturing immediate roof. When the fracturing heights are the same, the greater the fracturing angle, the better the stress relief.

The pressure in surrounding rock around retained gobside entry is relatively small after using BFRT through the 
field tests; and the maximum deformation changes of the roof, the coal rib, and the floor are $128 \mathrm{~mm}, 17 \mathrm{~mm}$, and $78 \mathrm{~mm}$; the control effect of the surrounding rock is good, which means that the BFRT used in retained gob-side entry is feasible and effective.

\section{Data Availability}

The research data used to support the findings of this study are included within the article. Request for more details should be made to the corresponding author.

\section{Conflicts of Interest}

The authors declare that they have no conflicts of interest.

\section{References}

[1] M. G. Qian, J. L. Xu, and J. C. Wang, "Further on the sustainable mining of coal," Journal of China Coal Society, vol. 43, no. 1, pp. 1-13, 2018.

[2] Z. Zhang, H. Shimada, D. Qian, and T. Sasaoka, "Application of the retained gob-side gateroad in a deep underground coalmine," International Journal of Mining, Reclamation and Environment, vol. 30, no. 5, pp. 371-389, 2016.

[3] F. He, H. Wenrui, D. Chen, S. Xie, H. Li, and C. He, "First fracture structure characteristics of main roof plate considering elastic-plastic deformation of coal," Journal of China Coal Society, vol. 45, no. 8, pp. 2704-2717, 2020.

[4] J. Fan, P. Liu, J. Li, and D. Jiang, "A coupled methane/air flow model for coal gas drainage: model development and finitedifference solution," Process Safety and Environmental Protection, vol. 141, pp. 288-304, 2020.

[5] A. Liu, S. Liu, X. Hou, and P. Liu, "Transient gas diffusivity evaluation and modeling for methane and helium in coal," International Journal of Heat and Mass Transfer, vol. 159, Article ID 1200091, 2020.

[6] G. Feng and P. Wang, "Stress environment of entry driven along gob-side through numerical simulation incorporating the angle of break," International Journal of Mining Science and Technology, vol. 30, no. 2, pp. 189-196, 2020.

[7] M. He, G. Zhu, and Z. Guo, "Longwall mining "cutting cantilever beam theory" and 110 mining method in China-The third mining science innovation," Journal of Rock Mechanics and Geotechnical Engineering, vol. 7, no. 5, pp. 483-492, 2015.

[8] Y. J. Wang, M. C. He, and J. Yang, "Case study on pressurerelief mining technology without advance tunneling and coal pillars in longwall mining," Tunnelling and Underground Space Technology, vol. 97, pp. 1-15, 2020.

[9] Z. Z. Zhang, W. J. Wang, S. Q. Li et al., "An innovative approach for gob-side entry retaining with thick and hard roof: a case study," Tehnički vjesnik, vol. 25, no. 4, pp. 1028-1036, 2018.

[10] B. Huang, J. Liu, and Q. Zhang, "The reasonable breaking location of overhanging hard roof for directional hydraulic fracturing to control strong strata behaviors of gob-side entry," International Journal of Rock Mechanics and Mining Sciences, vol. 103, pp. 1-11, 2018.

[11] Y. Tai, B. Yu, B. W. Xia, Z. Li, and H. C. Xia, "Research on stress release for the gob-side roadway using the roof-cutting technology with a chainsaw arm," Royal Society Open Science, vol. 7, no. 3, pp. 1-11, 2020.
[12] X. Ma, M. He, D. Liu, L. He, and Q. Jiang, "Study on mechanical properties of roof rocks with different cutting inclinations," Geotechnical and Geological Engineering, vol. 37, no. 4, pp. 2397-2407, 2019.

[13] G. Y. Hou, T. Hu, Z. X. Li, Z. H. Li, J. P. Chen, and Y. K. Cui, "Effect of cutting roof height on the stability of gob-side retaining roadway with roadside support," Journal of Mining and Safety Engineering, vol. 36, no. 5, pp. 925-931, 2019.

[14] M. C. He, Y. B. Gao, J. Yang, and W. L. Gong, "An innovative approach for gob-side entry retaining in thick coal seam longwall mining," Energies, vol. 10, no. 11, pp. 1-22, 2017.

[15] Q. Bai, S. Tu, F. Wang, and C. Zhang, "Field and numerical investigations of gateroad system failure induced by hard roofs in a longwall top coal caving face," International Journal of Coal Geology, vol. 173, pp. 176-199, 2017.

[16] Y. J. Wang, Y. B. Gao, E. Y. Wang, M. C. He, and J. Yang, "Roof deformation characteristics and preventive techniques using a novel non-pillar mining method of gob-side entry retaining by roof cutting," Energies, vol. 11, no. 3, pp. 1-17, 2018.

[17] H. Y. Yang, Y. B. Liu, S. G Cao et al., "A caving self-stabilization bearing structure of advancing cutting roof for gobside entry retaining with hard roof stratum," Geomechanics and Engineering, vol. 21, no. 1, pp. 23-33, 2020.

[18] J. Yang, H. Y. Wang, Y. J. Wang, Y. B. Gao, J. W. Wang, and H. Liu, "Fracture characteristics of the roof in gob-sdie entry retaining with roof cutting and pressure release," Journal of Mining Safety, vol. 36, no. 6, pp. 1138-1144, 2019.

[19] L. Zhang, J. Zhao, C. Zang, and S. Wang, "An innovative approach for gob-side entry retaining by roof cutting in steeply pitching seam longwall mining with hard roof: a case study," Mining, Metallurgy \& Exploration, vol. 37, no. 4, pp. 1079-1091, 2020.

[20] G.-C. Zhang, F.-L. He, H.-G. Jia, and Y.-H. Lai, "Analysis of gateroad stability in relation to yield pillar size: a case study," Rock Mechanics and Rock Engineering, vol. 50, no. 5, pp. 1263-1278, 2017.

[21] L. Jiang, P. Zhang, L. Chen et al., "Numerical approach for goaf-side entry layout and yield pillar design in fractured ground conditions," Rock Mechanics and Rock Engineering, vol. 50, no. 11, pp. 3049-3071, 2017.

[22] M. Salamon, "Mechanism of caving in longwall coal mining. Rock mechanics contributions and challenges," in Proceedings of the 31st US Symposium on Rock Mechanics, pp. 161-168, Golden, Colorado, USA, January 1990.

[23] H. Yavuz, "An estimation method for cover pressure re-establishment distance and pressure distribution in the goaf of longwall coal mines," International Journal of Rock Mechanics and Mining Sciences, vol. 41, no. 2, pp. 193-205, 2004.

[24] L. Jiang, A. Sainoki, H. S. Mitri, N. Ma, H. Liu, and Z. Hao, "Influence of fracture-induced weakening on coal mine gateroad stability," International Journal of Rock Mechanics and Mining Sciences, vol. 88, pp. 307-317, 2016.

[25] B. G. D. Smart and S. M. Haley, "Further development of the roof strata tilt concept for pack design and the estimation of stress development in a caved waste," Mining Science and Technology, vol. 5, no. 2, pp. 121-130, 1987. 